\title{
Correlation of Environmental Factors with Nitrate Concentration in Meadow Plants
}

\author{
F.B. GOMM
}

\begin{abstract}
Earlier studies of meadow forages in eastern Oregon have shown that fertilizer- $\mathrm{N}$ increased yields and $\mathrm{N}$ concentration. How much of the increased $\mathrm{N}$ was $\mathrm{NO}_{3}-\mathrm{N}$ or how variations in environmental factors affected the accumulation of $\mathrm{NO}_{3}$ in meadow plants is not known. Plots of native meadow were fertilized on March 31 with ammonium sulfate to provide nitrogen levels of $0,110,220,440$ $\mathrm{kg} / \mathrm{ha}$. Changes in air temperature; soil temperature at the 0-, 5-, $10-, 20-$, and 50-cm depths; luminous flux at canopy level, at $20 \mathrm{~cm}$ above ground, and at ground level; solar radiation over vegetation; and soil moisture content were monitored through the growing season. These data were statistically correlated with concentrations of $\mathrm{NO}_{3}-\mathrm{N}$ extracted from plant tissue. Herbage yields at the end of the growing season increased from $4,275 \mathrm{~kg} / \mathrm{ha}$ without fertilizer to $9,782 \mathrm{~kg} / \mathrm{ha}$ with $440 \mathrm{~kg} \mathrm{~N} / \mathrm{ha}$. Total-N concentration was highest $(3.33 \%)$ on May 5 in herbage fertilized with $440 \mathrm{~kg}$ $\mathrm{N} / \mathrm{ha}$. As plants matured, concentration of total-N decreased by August 29 to $1.15 \%$ in plants receiving the $440 \mathrm{~kg} / \mathrm{ha}$ rate and to $0.72 \%$ in unfertilized plants and was higher in the leaves than in the stems. Conversely, concentration of $\mathrm{NO}_{3}-\mathrm{N}$ were lowest (10-70 ppm) early in the season. Late in the growing season the $\mathrm{NO}_{3}-\mathrm{N}$ level was lowest in the leaves and highest $(1,060 \mathrm{ppm})$ in the stems. Correlation analyses indicated that soil-moisture content was the most significant environmental factor correlated with accumulations of $\mathrm{NO}_{3}-\mathrm{N}$, except for soil fertility as measured by increased fertilization rate. Luminous flux at ground level and air temperature were also contributing factors.
\end{abstract}

Native plants commonly found on flood meadows of eastern Oregon are tolerant to long periods of flooding. These plants thrive under seasonally moist to saturated soil conditions, yet survive periodic droughts. With nitrogen $(\mathrm{N})$ fertilization, these meadow plants generally have increased yields and increased $\mathrm{N}$ content of the herbage (Rumburg

Author is range scientist, U.S. Dep. Agr.-SEA-Agr. Res., Crops Research Lab., Utah State University, Logan, 84322. Formerly at Oregon State University, Squaw Butte Agricultural Experiment Station, Burns, Ore.

This study represents the cooperative investigation of the U.S. Dep. Agr.-SEA-Agr. Res. and the Agr. Exp. Sta., Oregon State Univ. Tech. Pap. No. 4915 of the latter. Manuscript received January 8, 1979.
1969 and 1972). In these meadows, the level of herbage- $N$ increased rapidly after fertilizer was applied, then decreased gradually until the $\mathrm{N}$ concentration of the fertilized herbage resembled that of nonfertilized plants (Rumburg 1972). How much of the $\mathrm{N}$ content in the herbage was $\mathrm{NO}_{3}$ or how long the $\mathrm{NO}_{3}$ persisted in the plants as they matured was not studied. In similar fertilizer studies, but with different grass species, Lewis (1960), Slinkard (1964), and Willhite et al. (1955) also observed increased yields and high total- $N$ concentrations.

Although few cattle deaths in Oregon have been attributed to $\mathrm{NO}_{3}$ poisoning, cattle using high-nitrogen forage in other areas have died. Nitrate poisoning is not limited to cattle grazing plants that have been fertilized with $\mathrm{N}$. It also occurs when cattle graze plants after environmental stress. Primary factors known to affect plant accumulation of $\mathrm{NO}_{3}$ include nutrient supply, moisture stress, light, soil type, herbicides, and disease (McKee 1962).

The primary objective of this study was to determine the relationship of temperature, light, soil moisture, and fertilizer to $\mathrm{NO}_{3}$ accumulation in native meadow plants.

\section{Materials and Methods}

Plots $(3 \times 6 \mathrm{~m})$ arranged in a $4 \times 4$ Latin square, were located on a native flood meadow of the Squaw Butte Experiment Station, near Burns, Oregon. The vegetation was a mixture of grasses and sedges, dominantly beardless wildrye (Elymus triticoides Buckl.) with slender sedge (Carex praegracilis W. Boott) and Nevada bluegrass (Poa nevadensis Vasey ex Scribn.). Ammonium sulfate was applied March 31 to provide nitrogen levels of $0,110,220$, and $440 \mathrm{~kg} / \mathrm{ha}$. The soil was flooded with standing water from May 1 until June 26 and then allowed to dry. Rainfall from March 31 to May 1 was less than $0.5 \mathrm{~cm}$, and during the drying period it was less than $1.25 \mathrm{~cm}$.

Ten grab samples of herbage was taken at 3-week intervals from May 5 until August 29 by clipping herbage to ground level. After 
June 2, samples were collected separately from upper leaves, midstem, and lower stem of the plant. The final yield was taken on August 29 by harvesting $1-\mathrm{m}^{2}$ sample from each treatment plot. Each herbage sample was dried at $65^{\circ} \mathrm{C}$ for 48 hours, ground, and analyzed for total- $\mathrm{N}, \mathrm{NO}_{3}-\mathrm{N}$, and $\mathrm{NH}_{4}-\mathrm{N}$ by Kjeldahl and microKjeldahl methods (Bremner and Keeney 1966, as modified for plants by Oregon State University Soil Testing Laboratory). Phenological development and plant height were recorded periodically.

Soil samples were taken on May 5 and October 6 from the surface $30 \mathrm{~cm}$ of soil. The soil was dried, ground, and analyzed for $\mathrm{NO}_{3}-\mathrm{N}$ and $\mathrm{HH}_{4}-\mathrm{N}$ by the micro-K jeldahl method for soil (Bremner and Keeney 1966).

The following environmental factors were monitored: air temperatures, daily maxima and minima at the standard 1-m height; luminous flux at canopy level, at $20 \mathrm{~cm}$ above ground, and at ground level was recorded at 1-hour intervals on designated days. Luminous flux from blue sky may be converted to photosynthetic irradiance in the 400-700 nm wave band where $\mathrm{W} / \mathrm{m}^{2} \mathrm{klux}$ 4.88 (McCree 1972). Luminous flux was measured with a Kahlsico

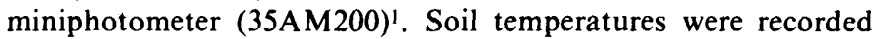
daily at the $10-\mathrm{cm}$ depth using an Instrument Corporation recording thermograph. On selected dates, soil temperature was recorded at 2-hour intervals at $0-, 5-, 10-, 20-$, and 50-cm depths on fertilized and unfertilized plots. These temperature measurements were made using thermocouples constructed from Honeywell constantan-copper wire (Model 1W2P6), as indicated on a Honeywell potentiometer (Model 2736). Solar radiation over vegetation was determined with a constant recording pyrheliograph (Belfort Instrument Company, No. 53850). Net radiation was determined with a portable net radiation indicator (C.W. Thornwaite Associated, Model 603). Air temperatures were recorded on a constant recording hygrothermograph (Belfort Instrument Company, No. 5-594). Soil moisture content was cvaluated by drying soil samples at $105^{\circ} \mathrm{C}$ for 48 hours and determining moisture content gravimetrically.

\section{Results and Discussion}

\section{Environmental Influences}

\section{Soil Moisture}

From May 1 to June 26 the soil remained saturated. The flooding depth was never greater than $2.5 \mathrm{~cm}$ and was uniform across the study plots. After July 1, the soil gradually dried until the end of the experiment (Table 1).

\section{Soil $N$}

Soil analyses indicated that in early May the residual- $N$ was in the $\mathrm{NH}_{4}$ form. At that time available- $\mathrm{N}$ in the saturated soil was less than 1 ppm $\mathrm{NO}_{3}$. The $\mathrm{NH}_{4}-\mathrm{N}$ concentra-

'Mention of a product does not constitute a guarantee or warranty by the U.S. Dep. Agr. tion, however, was $13.7 \mathrm{ppm}$ in unfertilized plots and increased in fertilized plots. As the soil dried, the $\mathrm{NO}_{3}-\mathrm{N}$ in unfertilized plots increased to $13.9 \mathrm{ppm}$, and $\mathrm{NH}_{4}-\mathrm{N}$ decreased to $2.8 \mathrm{ppm}$. These changes in $\mathrm{N}$-form agreed with the findings of Van Schreven and Sieben (1972). By October 6 , the differences in soil $\mathrm{N}$ concentrations were minimal among fertilizer rates.

\section{Radiation.}

Solar radiation at the field site range from 1.0 to 1.5 $\mathrm{ly} / \mathrm{min}$ (Table 1). In May and June 600 to $750 \mathrm{ly} /$ day were received. In July, August, and September solar radiation decreased to 625,575 , and $480 \mathrm{ly} /$ day, respectively. The average net radiation received at the plants from June 2 to August 17 was about $50 \%$ of the solar radiation.

\section{Irradiance}

Light measurements on June 22 show that about 107,500 lux $\left(525 \mathrm{~W} / \mathrm{m}^{2}\right)$ was received at canopy level for about 45 minutes. Within the cover of the unfertilized vegetation, the irradiance level was above 32,000 lux $\left(156 \mathrm{~W} / \mathrm{m}^{2}\right)$ for 2 hours, whereas at ground level it was above 10,750 lux (52.5 $\mathrm{W} / \mathrm{m}^{2}$ ) for about 3.3 hours. Within the cover of grass fertilized with $440 \mathrm{~kg} \mathrm{~N} /$ ha, irradiance levels were 8,500-107,750 lux $\left(41.5-52.5 \mathrm{~W} / \mathrm{m}^{2}\right)$ for 2.5 hours. At the soil surface the irradiance level was above $1,075 \mathrm{lux}\left(5.2 \mathrm{~W} / \mathrm{m}^{2}\right)$ for only 4 hours. For other dates irradiance levels at the soil surface were shown in Figure 1.

The amount of light that reached the lower plant parts was greater earlier than later in the growing season. It was also much greater within unfertilized vegetation than within the fertilized. As the season progressed and the herbage became dense, less light penetrated the canopy (Table 1). By the end of August, the luminous flux level received at the lower plant stem of fertilized vegetation was reduced to 108 $\operatorname{lux}\left(0.5 \mathrm{~W} / \mathrm{m}^{2}\right)$.

\section{Soil Temperature}

Early in the season, soil temperatures were similar under the meadow vegetation of the unfertilized and fertilized plots. By May 31, however, the temperature at the $10-\mathrm{cm}$ soil depth was higher under unfertilized vegetation than it was under fertilized vegetation. From June 14 to September 10 , the soil at the $50-\mathrm{cm}$ depth was $1^{\circ} \mathrm{C}$ warmer under the unfertilized vegetation than it was under the fertilized, whereas the soil surface the temperature was 4 to $5^{\circ} \mathrm{C}$ warmer under unfertilized vegetation.

From June 22 to August 19, the average temperature of the surface soil in unfertilized plots was $16^{\circ} \mathrm{C}$ at 0700 hours;

Table 1. Environmental data from fertilized meadow on various sampling dates.

\begin{tabular}{|c|c|c|c|c|c|c|c|}
\hline Date (1972) & $\begin{array}{c}\text { Days from } \\
\text { May } 1 \\
\text { No. }\end{array}$ & $\begin{array}{l}\text { Maximum } \\
\text { air } \\
\text { temperature } \\
{ }^{\circ} \mathrm{C}\end{array}$ & $\begin{array}{l}\text { Maximum } \\
\text { surface soil } \\
\text { temperature } \\
{ }^{\circ} \mathrm{C}\end{array}$ & $\begin{array}{l}\text { Maximum soil } \\
\text { temperature } \\
\text { at } 10-\mathrm{cm} \text { depth } \\
{ }^{\circ} \mathrm{C}\end{array}$ & $\begin{array}{c}\text { Maximum } \\
\text { irradiance at } \\
\text { soil surfacel } \\
\text { lux }\end{array}$ & $\begin{array}{l}\text { Solar } \\
\text { radiation } \\
\mathrm{ly} / \mathrm{min}\end{array}$ & $\begin{array}{c}\text { Soil } \\
\text { moisture } \\
\text { content } \\
\%\end{array}$ \\
\hline May 5 & 5 & 17 & 24 & 15 & 3762 & 1.3 & 54 \\
\hline May 24 & 24 & 17 & 24 & 15 & 4300 & 1.3 & 55 \\
\hline June 2 & 33 & 26 & 30 & 20 & 5375 & 1.4 & 54 \\
\hline June 22 & 53 & 26 & 30 & 18 & 3225 & 1.5 & 59 \\
\hline July 7 & 68 & 28 & 28 & 18 & 430 & 1.5 & 46 \\
\hline July 24 & 85 & 28 & 31 & 18 & 322 & 1.3 & 38 \\
\hline August 17 & 109 & 20 & 25 & 16 & 161 & 1.2 & 28 \\
\hline August 29 & 121 & 31 & 26 & 18 & 108 & 1.0 & 24 \\
\hline
\end{tabular}

Irradiance was measured with a photometer in luminous flux. 


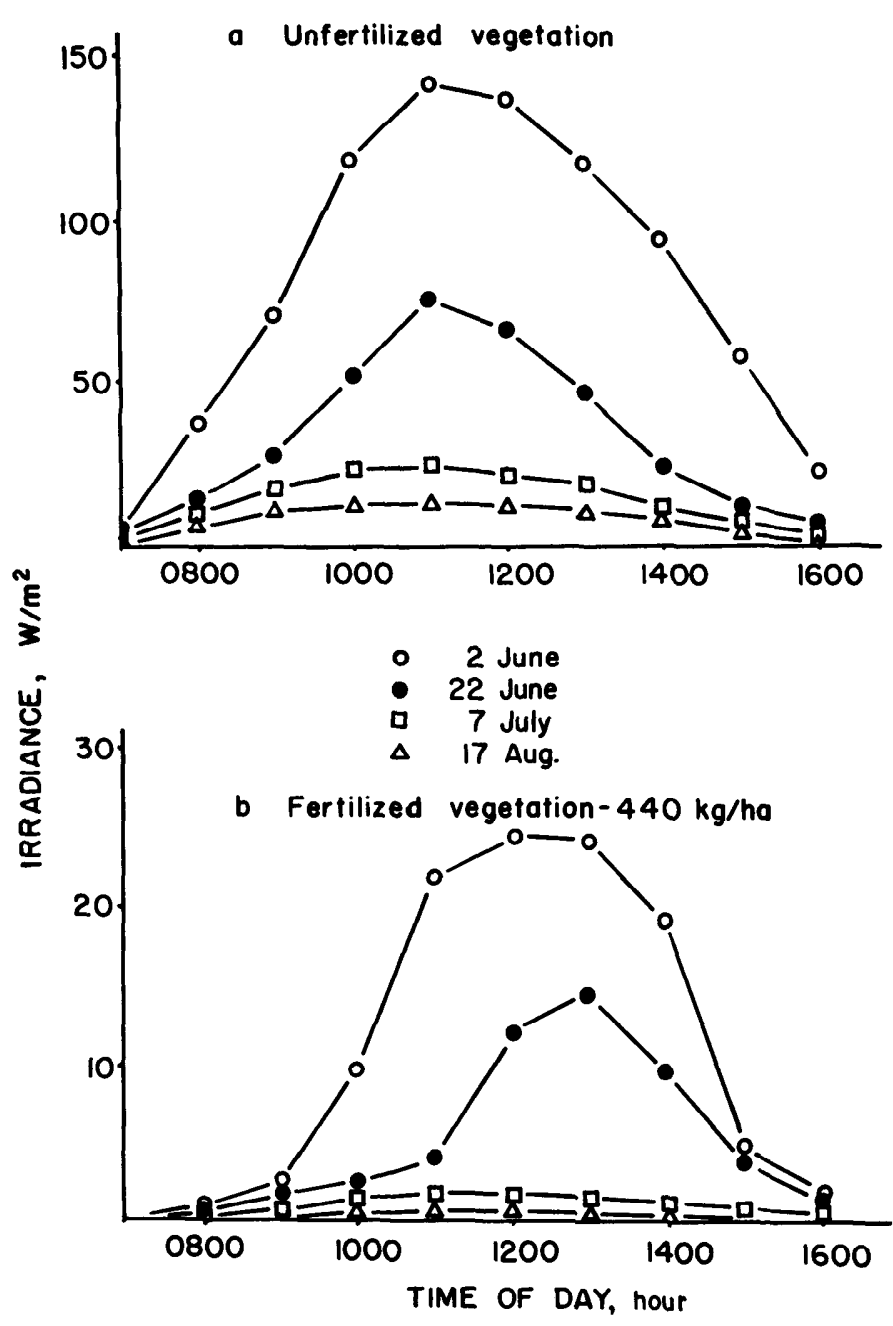

Fig. 1. Irradiance at the soil surface under meadow vegetation, unfertilized (a) and fertilized (b). Note scale differences between (a) and (b).

it then rose to a high of $32^{\circ} \mathrm{C}$ at 1300 hours. Under vegetation fertilized with $440 \mathrm{~kg} \mathrm{~N} / \mathrm{ha}$, the highest temperature was $25^{\circ} \mathrm{C}$.

At the 5-cm depth, the temperature was warmed to $25^{\circ} \mathrm{C}$ by May 31 under unfertilized vegetation. This was $3^{\circ} \mathrm{C}$ warmer than it was under fertilized vegetation. By August 9 , the maximum temperature under unfertilized vegetation was $28^{\circ} \mathrm{C}$, and the difference in soil temperature between the two treatments widened to $6^{\circ} \mathrm{C}$ then narrowed again, until on September 10 the soil from the unfertilized treatment was $1^{\circ} \mathrm{C}$ warmer than it was under fertilized vegetation.

At the 20-cm depth the soil reached its maximum temperature of $18^{\circ} \mathrm{C}$ in mid-August at 0900 hours under unfertilized vegetation. The temperature of the soil was 2 to $3^{\circ} \mathrm{C}$ warmer under the unfertilized treatment than under the fertilized vegetation.

Although soil temperature change lagged in relation to time and depth in sine-wave patterns, the variation in temperature below $20 \mathrm{~cm}$ was fairly constant with a daily range of 3 to $5^{\circ} \mathrm{C}$.

\section{Phenological Development}

Meadow plants began to grow about the first of April, but little difference among fertilizer treatments was observed until May 10. By May 20 plants receiving 220 and $440 \mathrm{~kg}$ $\mathrm{N} /$ ha were taller than those receiving the $110 \mathrm{~kg} / \mathrm{ha}$ rate or

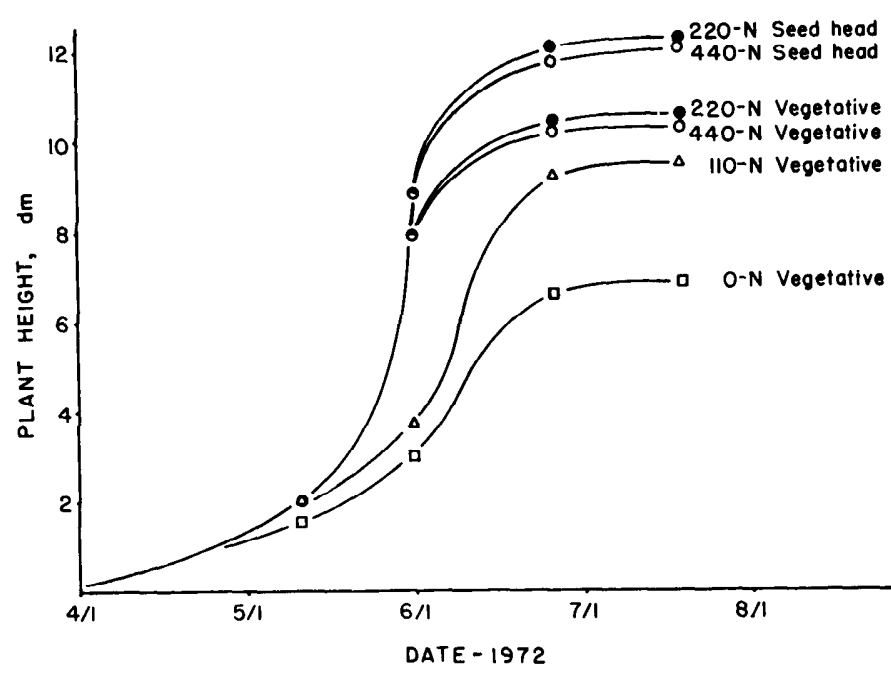

Fig. 2. Height and development of beardless wildrye as affected by nitrogen fertilization.

less (Fig. 2). The differences among treatments continued to widen until June 22, when most plants approached their maximum height. Some plants receiving 220 and $440 \mathrm{~kg}$ $\mathrm{N} /$ ha developed seed heads, but those receiving 0 and $110 \mathrm{~kg}$ $\mathrm{N} /$ ha developed only vegetative stems. Yields on August 29 increased as rates of fertilizer- $\mathrm{N}$ increased (Table 2).

Table. 2. Yield and nitrogen recovered from meadow herbage of plants harvested August 29 as affected by fertilizer rate.

\begin{tabular}{ccccc}
\hline $\begin{array}{l}\text { Fertilizer } \\
\text { rate of } \mathrm{N} \\
(\mathrm{kg} / \mathrm{ha})\end{array}$ & $\begin{array}{c}\text { Herbage } \\
\text { yield } \\
\mathrm{kg} / \mathrm{ha}\end{array}$ & $\begin{array}{c}\text { Concentra- } \\
\text { tion of } \mathrm{N} \text { in } \\
\text { herbage } \\
\%\end{array}$ & $\begin{array}{c}\text { Nitrogen } \\
\text { in } \\
\text { herbage } \\
\mathrm{k} / \text { gha }\end{array}$ & $\begin{array}{c}\text { Efficiency } \\
\text { of } \\
\text { fertilizer } \\
\%\end{array}$ \\
\hline 0 & 4198 & $0.80 \mathrm{a}^{2}$ & $33 \mathrm{a}$ & - \\
110 & 6969 & $0.77 \mathrm{a}$ & $53.7 \mathrm{~b}$ & 19 \\
220 & 8046 & $0.72 \mathrm{a}$ & $57.9 \mathrm{~b}$ & 11 \\
440 & 9607 & $1.15 \mathrm{~b}$ & $110.5 \mathrm{c}$ & 18 \\
\hline
\end{tabular}

${ }^{\prime} L S D_{0.01}=150 \mathrm{~kg} / \mathrm{ha}$.

${ }^{2}$ Values in columns followed by different letters are significantly different at $P<0.05$ according to Duncan's multiple range test.

The low irradiance level within the fertilized vegetation late in the season caused the shaded leaves to yellow as in senescence. Salisbury and Ross (1969) suggested that senescence is the result of altered hormone balance that prevents the production of enzymes synthesized when the cells were younger. It is, therefore, reasonable to believe that the irradiance level at the lower parts of these plants may have been too low to continue the life processes of the lower leaves, and yellowing resulted from light deficiency, not maturation.

\section{Chemical Analyses}

Ammonium Concentration

The normal $\mathrm{NH}_{4}-\mathrm{N}$ level in meadow plant tissue, predominantly beardless wildrye, appears to be 50 to $80 \mathrm{ppm}$ (Table 3). Unfertilized plants remained within this concentration range throughout the season. Fertilized plants seemed to contain their highest $\mathrm{NH}_{4}-\mathrm{N}$ levels early in the season with concentrations decreasing as the season advanced. This consistent decrease was observed particularly in herbage from plants which received fertilizer- $\mathrm{N}$ at the 440 and $220 \mathrm{~kg} \mathrm{~N} / \mathrm{ha}$ rates. 
Table 3. Ammonium and nitrate concentration (ppm) in meadow herbage as affected by fertilizer- $N$ levels and seasonal growth'.

\begin{tabular}{lcccc}
\hline Sampling & \multicolumn{3}{c}{ Concentrations at four rates of $\mathbf{N}(\mathrm{kg} / \mathrm{ha})$} \\
\cline { 2 - 5 } date & 0 & 110 & 220 & 440 \\
\hline Ammonium-nitrogen & & & \\
May 5 & 50 & 170 & 130 & 170 \\
May 24 & 80 & 90 & 110 & 160 \\
June 2 & 60 & 30 & 180 & 180 \\
June 22 & 50 & 50 & 90 & 130 \\
July 7 & 70 & 20 & 60 & 100 \\
July 24 & 60 & 60 & 60 & 80 \\
Aug. 17 & 60 & 40 & 50 & 80 \\
Aug. 29 & 70 & 90 & 40 & 70 \\
Nitrate-nitrogen & & & & \\
May 5 & 10 & 40 & 10 & 70 \\
May 24 & 30 & 20 & 10 & 80 \\
June 2 & 10 & 10 & 80 & 200 \\
June 22 & 10 & 10 & 10 & 300 \\
July 7 & 10 & 10 & 10 & 340 \\
July 24 & 10 & 10 & 10 & 340 \\
Aug. 10 & 70 & 10 & 30 & 440 \\
Aug. 29 & 20 & 70 & 10 & 580 \\
\hline
\end{tabular}

'Beardless wildrye was the predominant species.

\section{Total- $N$ Concentration}

The concentration of total- $\mathrm{N}$ early in the season was highest in herbage fertilized with $440 \mathrm{~kg} \mathrm{~N} /$ ha (Fig. 3). As plants matured, total-N levels decreased. After June 1, total$\mathrm{N}$ concentrations were similar at rates of $\mathrm{N}$ less than 220 $\mathrm{kg} / \mathrm{ha}$. Although statistical analyses indicated no differences in total-N from fertilizer treatments on July 24 and August 17, mean concentrations were consistently highest in herbage treatments receiving $440 \mathrm{~kg} \mathrm{~N} / \mathrm{ha}$. From May 24 to July 7 , the differences in total-N concentrations among fertilizer treatments were highly significant $(P<0.01)$. This result was primarily due to the high concentration of $N$ in plants fertilized with $440 \mathrm{~kg} \mathrm{~N} / \mathrm{ha}$.

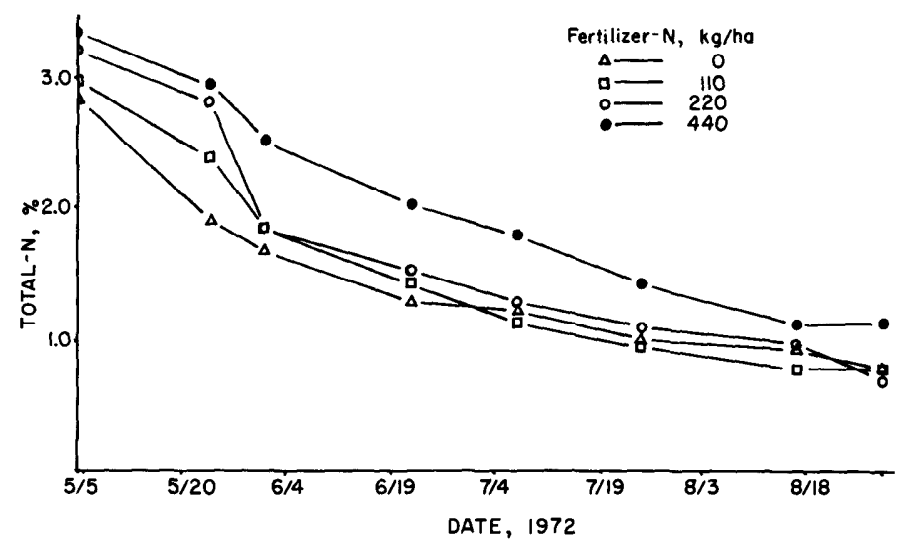

Fig. 3. Concentration of total- $N$ in meadow forage at various dates as affected by fertilizer rate.

Total-N concentrations were highest in leaf tissue in early May with no difference among fertilizer treatments. In early June, the total- $\mathrm{N}$ in the stem tissue was relatively high but not as high as it was in the leaves and the concentration was highest with $440 \mathrm{~kg} \mathrm{~N} /$ ha (Fig. 4). As the season advanced, total- $\mathbf{N}$ concentrations in both leaves and stems decreased so that near the end of the season and the unfertilized stems contained about $0.6 \%$ total- $\mathrm{N}$, and those fertilized with 440 $\mathrm{kg} \mathrm{N} /$ ha contained $0.9 \%$ total-N. At the same times leaves

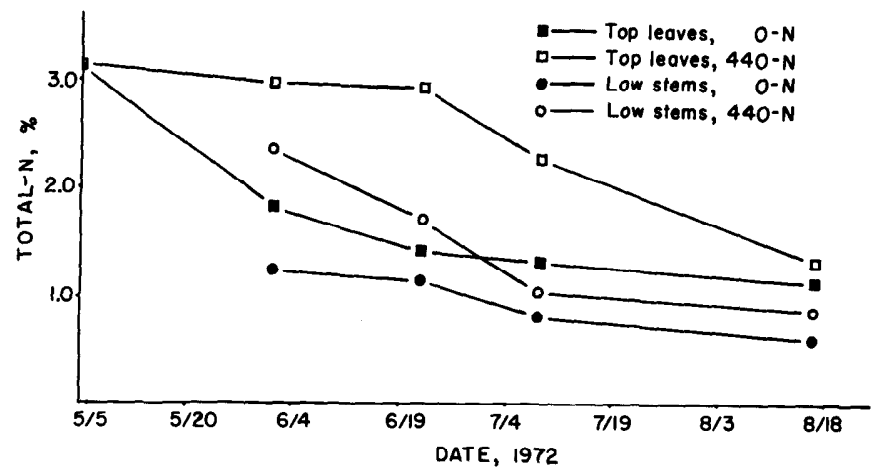

Fig. 4. Concentration of total- $N$ in tissue of meadow forage as affected by fertilizer rate.

contained 1.2 and $1.5 \%$ total- $\mathrm{N}$ at the $0-$ and $440-\mathrm{kg} \mathrm{N} /$ ha rates, respectively. Less than $20 \%$ of the $\mathrm{N}$ applied was used in herbage production (Table 2).

\section{Nitrate $N$}

The normal level of the $\mathrm{NO}_{3}-\mathrm{N}$ in the meadow herbage, predominantly beardless wildrye, appears to be less than 10 ppm (Table 3). Except for occasional increases, only traces of $\mathrm{NO}_{3}-\mathrm{N}$ were measured from samples receiving $220 \mathrm{~kg}$ $\mathrm{N} /$ ha or less. Nevertheless, the $440 \mathrm{~kg} \mathrm{~N} /$ ha rate caused the $\mathrm{NO}_{3}-\mathrm{N}$ level to increase. During the flooding period, while the soil was saturated, the $\mathrm{NO}_{3}-\mathrm{N}$ concentration in herbage from the $440 \mathrm{~kg} \mathrm{~N} /$ ha treatment was significantly lower than later when the soil was dry. The highest $\mathrm{NO}_{3}-\mathrm{N}$ concentration in the herbage occurred during August when the soil was driest (Table 1).

The production and activation of nitrate reductase is a light-stimulated reaction (Hageman and Flesher 1960). Therefore, the $\mathrm{NO}_{3}$ concentration in the stems and lower, shaded leaves should be higher than that in leaves exposed to full sunlight. Early in June, 80 and $220 \mathrm{ppm} \mathrm{NO}_{3}-\mathrm{N}$ in the lower stems was detected from the 220 and $440 \mathrm{~kg} \mathrm{~N} / \mathrm{ha}$ rates, respectively. During late June under the $440 \mathrm{~kg} \mathrm{~N} / \mathrm{ha}$ treatment, the $\mathrm{NO}_{3}-\mathrm{N}$ level increased to $240 \mathrm{ppm}$ in the upper leaves, $990 \mathrm{ppm}$ in the midstem, and $1,060 \mathrm{ppm}$ in the lower stem. During July and August, the $\mathrm{NO}_{3}-\mathrm{N}$ level remained higher in the lower stem than in upper leaves, but concentrations were never high enough to be toxic $(2,100$ ppm $\mathrm{NO}_{3}-\mathrm{N}$ ) to livestock.

Simple correlation analyses were used to test the assumption that the $\mathrm{NO}_{3}-\mathrm{N}$ increase late in the season was related to decreasing soil moisture and increasing shade at ground level-both of which were associated with advance in season. Only data for $\mathrm{NO}_{3}-\mathrm{N}$ concentration in herbage from plots fertilized with $\mathrm{N}$ at $440 \mathrm{~kg} / \mathrm{ha}$ were used.

Days from May 1 accounted for $94 \%$ of the variation (Fig. 5). Decreasing soil moisture content was the most significant factor correlated with $\mathrm{NO}_{3}-\mathrm{N}$ accumulation (Fig. 6a). Luminous flux at ground level (Fig. 6b) and maximum air temperature (Fig. 6c) were also weakly correlated with the $\mathrm{NO}_{3}-\mathrm{N}$ accumulation $(P<0.05)$. These three factors, soil moisture, light, and air temperature, are interrelated with stage of growth (days from May 1), seasonal influences, and characteristics of plant growth that tend to be related with time to the $\mathrm{NO}_{3}$ concentration. Multiple correlation analysis of these factors compared closely with the simple correlation of analysis of days from May 1 (Fig. 5). Multiple correlation accounted for about $97 \%$ of the variation. Solar radiation at 


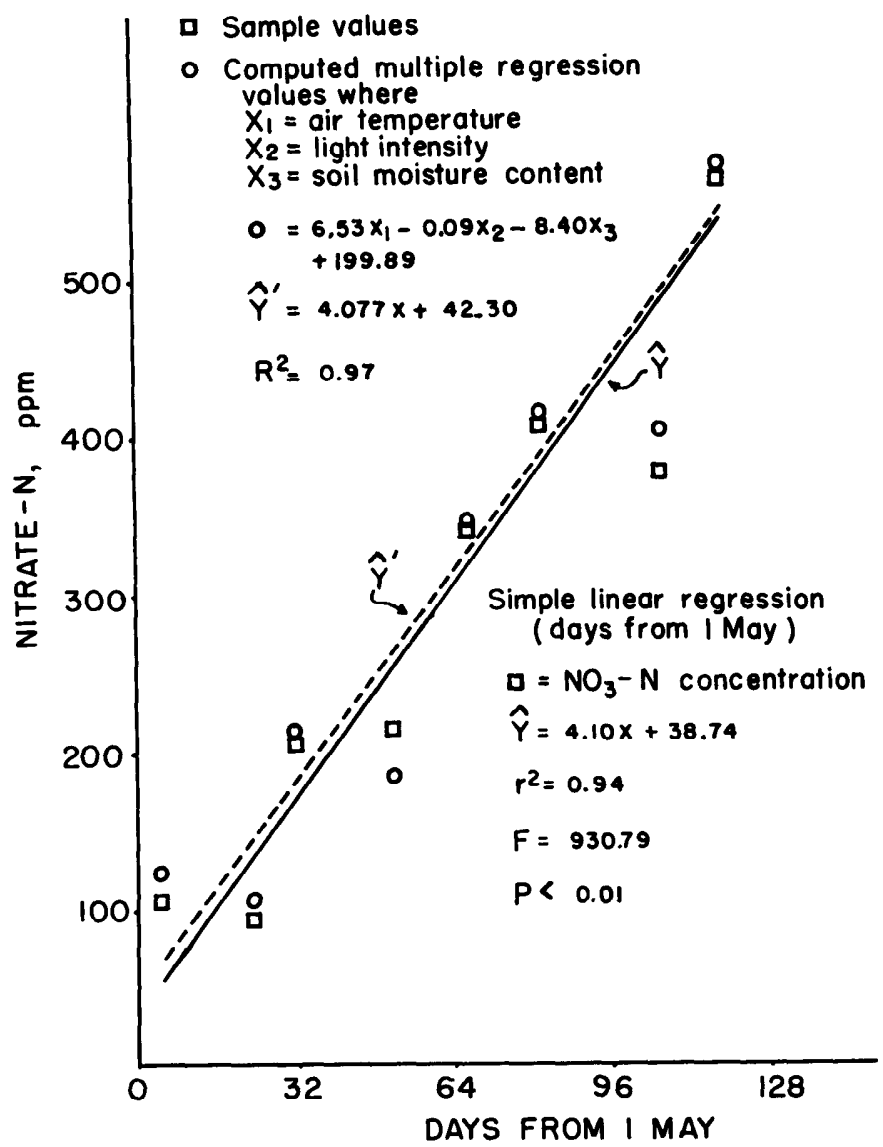

Fig. 5. The correlation of time (seasonal development) to the accumulation of $\mathrm{NO}_{3}$ in meadow forage as expressed by simple and multiple correlation analyses. In the multiple correlation analysis, air temperature (maxima at $1300 \mathrm{hr}$ ), light intensity (maxima luminous flux), and soil moisture content on sampling dates were used to derive computed multiple correlation values.

canopy level (Fig. 6e) and the soil temperature at the soil surface (Fig. 6f) and at the 10-cm depth (Fig. 6d) were nonsignificant factors in simple correlation analyses.

Considering the simple correlation coefficients of $\mathrm{NO}_{3}-\mathrm{N}$ concentration with luminous flux $\left(r_{1.2}=-0.818\right)$ and with soil moisture stress $\left(r_{2.1}=0.885\right)$, both variables seemed to be strongly related to $\mathrm{NO}_{3}-\mathrm{N}$ accumulation in the plants, and the corresponding coefficient of multiple correlation $(R=$ 0.89 ) suggests that $80 \%$ of the deviation from the mean was explained by the influence of these two variables. A comparison of the standard partial regression coefficients for $\mathrm{NO}_{3}$ $\mathrm{N}$ concentration by luminous flux $\left(\mathrm{b}_{1.2}=-0.010\right)$ and by soil-moisture stress $b_{2.1}=0.793$ ) showed that the $Y X_{2}$ relationship was strong whereas the $Y X_{1}$ relationship was less strong. The $F$ test $(P=0.05)$ indicated with good confidence that most of the deviation was due to the influence of soil-moisture stress and luminous flux of the light source.

The overriding effect of soil moisture on $\mathrm{NO}_{3}$ concentration is well demonstrated. The normal response is for the $\mathrm{NO}_{3}$ level to decrease as plants mature. However, plants common to the meadows of eastern Oregon contained relatively low $\mathrm{NO}_{3}$ levels in the early summer, when the soil was saturated, as compared with the increased $\mathrm{NO}_{3}$ levels when the soil dried. To high correlation of $\mathrm{NO}_{3}$ level with soil moisture content substantiated this observation (Fig. 6a). Several authors have reported studies which help explain
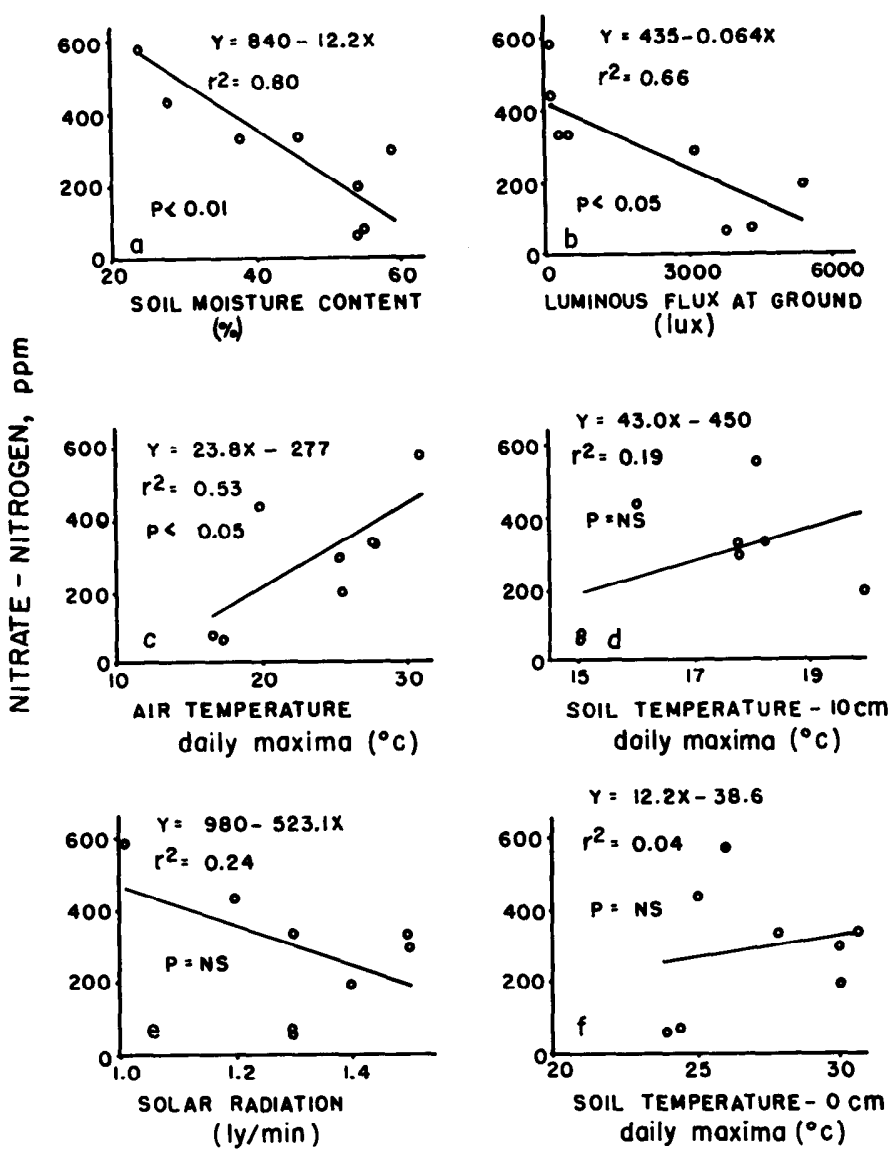

Fig. 6. Nitrate concentration in meadow forage as correlated with environmental variables determined at $1300 \mathrm{hr}$ on date of sampling.

these results. Spratt and Gasser (1970), Plaut (1973), Terman et al. (1969), and Tisdale and Nelson (1966) have shown the importance of adequate soil moisture for efficient use of $\mathbf{N}$ by plants. Soil moisture influences the $\mathbf{N}$ available to plants as it affects the behavior of soil microorganisms. The activity of nitrifying organisms is inhibited at extremely low or extremely high moisture levels, which may reduce the supply of available $\mathbf{N}$. When soil becomes waterlogged, as it was during the flooding period of this experiment, oxygen is excluded and anaerobic decomposition occurs. The exclusion of oxygen and the activity of the anaerobic bacteria induced denitrification. Under the waterlogging conditions, $\mathrm{NO}_{3}$ could have been reduced and the $\mathrm{N}$ lost to the atmosphere. Also, because $\mathrm{NO}_{3}$ is extremely soluble in water, much of it could have been lost through leaching processes. As the soil moisture level decreased and oxygen became more available, ammonification of organic $\mathrm{N}$ could have taken place and the nitrifying processes increased the supply of $\mathrm{NO}_{3}$ in the soil, thus increasing the $\mathrm{NO}_{3}$ concentration in the plant material. Soil moisture not only controls the behavior of the $\mathbf{N}$ in the soil, but also affects $\mathrm{N}$ uptake and utilization by the plant. D'Aoust and Tayler (1968) and Holliday (1970) showed that the $\mathrm{N}$ uptake is inefficient when the root zone is depleted of water. Also, Garcia and Gomez (1972) observed that the variation in $\mathrm{NO}_{3}$ concentration depends on the water content of the herbage. They reported that the $\mathrm{NO}_{3}$ level in alfalfa plants increased as the water content decreased, and Gomm (1979) observed that meadow plants, grown under controlled environmental conditions, could accumulate potentially toxic levels of $\mathrm{NO}_{3}$ when 
soil moisture conditions were less than saturated. Plants grown in saturated soil contained levels of $\mathrm{NO}_{3}$ considered to be safe for cattle, even when plants were fertilized with $440 \mathrm{~kg} \mathrm{~N} / \mathrm{ha}$.

\section{Conclusion}

The rate of applied fertilizer- $\mathrm{N}$ was the most important of the factors considered that determined the level of $\mathrm{NO}_{3}$ accumulation in native meadow plants. At normal application rates (90-130 kg N/ha), however, it is unlikely that $\mathrm{NO}_{3}$ concentrations would accumulate to toxic levels. The primary reason that nitrate poisoning has not been associated with forage from fertilized meadows of eastern Oregon seems to be because of the saturated soil conditions during plant growth. Other environmental factors of secondary importance responsible for maintaining low levels of $\mathrm{NO}_{3}$ in the forage seems to be the high level of irradiance and the relatively low air temperatures characteristic of eastern Oregon.

\section{Literature Cited}

Bremner, J.M., and D.R. Keeney. 1966. Determination of isotope-ratio analysis of different forms of nitrogen in soils:3. Exchangeable ammonium nitrate and nitrite by extraction-distillation methods. Soil Sci. Soc. Amer. Proc. 30: 577-582.

D'Aoust, M.J., and R.S. Tayler. 1968. The interaction between nitrogen and water in the growth of grass swards. 1. Methods and dry matter results. J. Agr. Sci. 70: 11-17.

Garcia, B., and J.M. Gomez. 1972. The effect of various factors on the $\mathrm{NO}_{3}$ content of lucerne (Medicago sativa L.). Agrochimica 16: 409-417. (Herb Abstr. 43: 1187).

Gomm, F.B. 1979. Herbage yield and nitrate concentration in meadow plants as affected by environmental variables. J. Range Manage. 32: 359364.
Hageman, R.H., and D. Flesher. 1960. Nitrate reductase activity in corn seedlings as affected by light and nitrate content of nutrient media. Plant Physiol. 35: 700-708.

Holliday, R. 1970. Soil profile moisture and nitrogen availability. In: Kirklby, E.A. (ed.) Nitrogen Nutrition of the Plant. A Wigley and Sons. Leeds.

Lewis, R.D. 1960. Mountain meadow problems-with suggestions for improvement. Eleventh Fertilizer Conf. of the Pacific Northwest Proc. 59-64. Mimeo.

McCree, K.J. 1972. Test of current definitions of photosynthetically active radiation against leaf photosynthesis data. Agr. Meteorol. 10: 443-453.

McKee, H.S. 1962. Nitrogen Metabolism in Plants London and New York. 728 p.

Plaut, Z. 1973. Effect of soil moisture tension and nitrogen supply on nitrate reduction and accumultion in wheat seedlings. Plant Soil 38: 81-94.

Rumburg, C.B. 1969. Yield and $\mathrm{N}$ concentration of meadow hay fertilized with three N sources. Agron. J. 61: 824-825.

Rumburg, C.B. 1972. Yield and $N$ accumulation of meadow forage fertilized at advancing maturity with N. Agron. J. 64: 187-189.

Salisbury, F.B., and C. Ross. 1969. Plant Physiology. Wadsworth Publishing Co., Inc. 761 p.

Slinkard, A.E. 1964. Mountain meadow fertilization. Idaho Agr. Exp. Sta. Prog. Rep. 90.7 p. Mimeo.

Spratt, E.D., and J.K.R. Gasser. 1970. Effect of fertilizer-nitrogen and water supply on distribution of dry matter and nitrogen between the different parts of wheat. Can. J. Plant Sci. 50: 613-625.

Terman, G.L., R.E. Ramig, A.F. Dreier, and R.A. Olson. 1969. Yieldprotein relationships in wheat grain as affected by nitrogen and water. Agron. J. 61: 755-759.

Tisdale, S.L., and W.L. Nelson. 1966. Soil Fertility and Fertilizers. 2nd ed. The MacMillan Co., New York. 694 p.

Van Schreven, D.A., and W.H. Sieben. 1972. The effect of storage on soils under waterlogged conditions upon subsequent mineralization of nitrogen, nitrification, and fixation of ammonia. Plant Soil 37: 245-253.

Willhite, F.M., H.K. Rouse, and D.E. Miller. 1955. High altitude meadows in Colorado. 3. The effect of nitrogen fertilization on crude protein. Agron. J. 47: 117-121.

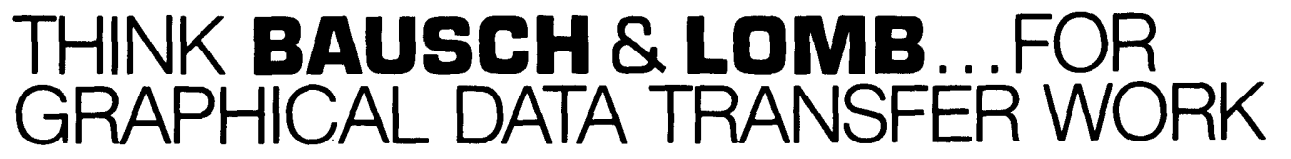

With a Bausch \& Lomb ZOOM TRANSFER SCOPE* instrument, you can quickly update a data base or prepare a special purpose thematic map without expensive data transfer, projection or darkroom equipment. These instruments work on the camera lucida principle that optically mix aerial photographs and data base without projection. Compare these performance features with what you are now using.

- Built-in scale and stretch correction systems compensate for photographic distortions. - Compact, lightweight design offers total portability. Can be used in a lighted office on any flat surface.

- Zoom control instantly matches photograph to data base scale.

- Accommodates all photographic formats including transparencies and prints (black and white or color). Stereo model (illustrated) helps you examine topographical and structural features. - Two models feature a photographic mode for permanent documentation.

\section{CALL US AT 716 338-6000}

And let a Bausch \& Lomb representative recommend the instrument that best meets your needs. Or, send coupon for illustrated literature.

"ZOOM TRANSFER SCOPE and Z.T.S. are trademarks of Bausch \& Lomb Incorporated for graphical data transfer instruments.
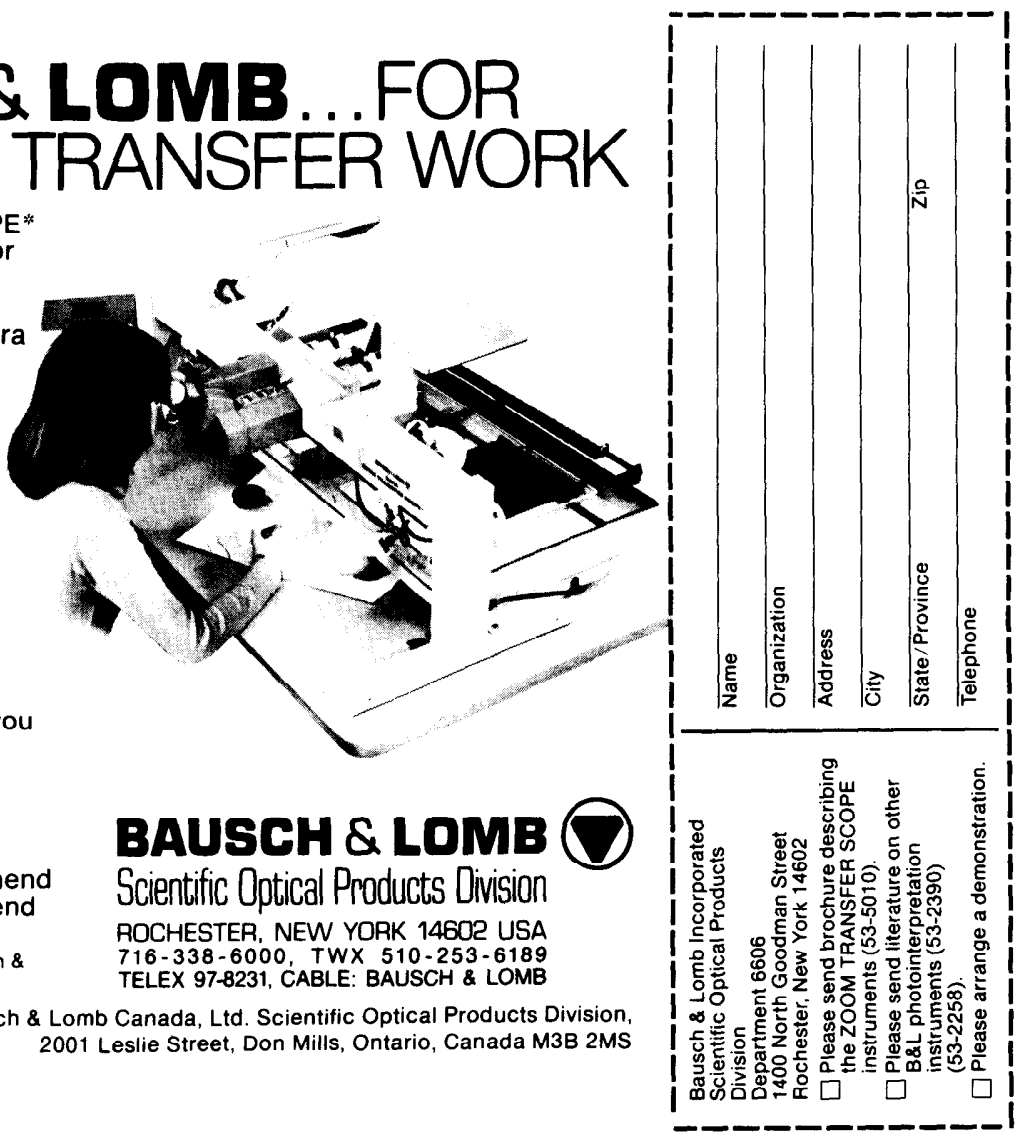

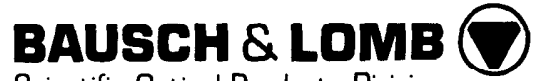
Scientific Optical Products Division ROCHESTER, NEW YORK 14602 USA $716-338-6000$, TWX 510-253-6189 TELEX 97-8231, CABLE: BAUSCH \& LOMB

In Canada: Bausch \& Lomb Canada, Ltd. Scientific Optical Products Division, 2001 Leslie Street, Don Mills, Ontario, Canada M3B 2MS 